\title{
A Study on Knowledge and Attitude Regarding Vaccines among Mothers of Under Five Children attending Pediatric OPD in a Selected Hospital at Mangalore
}

\author{
Ms.Mereena, $* *$ Mrs.Sujatha.R, $* * *$ \\ $* * M S c$ (N) Student, ***Prof. \& HOD, Department of Child Health Nursing, \\ Nitte Usha Institute Of Nursing Sciences, Constituent College Of Nitte University, Kotekar Beeri Road, Paneer, \\ Deralakatte, Mangalore- 575 018, Karnataka, India
}

\begin{abstract}
Immunization has saved the lives of more children than any other medical intervention in the last 50 years. Vaccines are safe, simple and one of the most cost-effective way to save and improve the lives of children. The present study was taken up to evaluate the knowledge and attitude among mothers of underfive, pertaining to immunization coverage. Results of the study revealed that, majority, 289 (96.33\%) mothers knew that BCG vaccine prevents Tuberculosis. Only 26(8.66\%) mothers were knowledgeable about the measures that can be done if the child has not given DPT. 11 (3.66\%) mothers knew that chicken pox can be prevented by varicella vaccine. The study concluded that even though the mothers had good attitude regarding vaccines, but they were unaware of Hib vaccine and rotavirus vaccine.
\end{abstract}

Key words: Vaccines, knowledge, attitude, mothers, underfive children, pediatric OPD

\section{Introduction}

"The child is God's gift to the family. Each child is created in the special image and likeness of God for greater things; to love and to be loved."

Vaccines work. Immunization has saved the lives of more children than any other medical intervention in the last 50 years. Vaccines are safe, simple and one of the most cost-effective way to save and improve the lives of children worldwide. However, many children in developing countries lack access to vaccines often because they live in hard-to-reach communities and are among the most marginalized members of the community. Vaccines ensure that all children, no matter their circumstances, have a shot at a healthy life

Children in India continue to lose their lives to vaccine-preventable diseases such as measles, which remains the bigger killer. Tetanus in newborn also remains a problem. Diarrhea remains the second major cause of death among children, after respiratory-tract infections. Unhygienic practices and unsafe drinking water are some of its main causes ${ }^{4}$ Immunization saves more than 3 million lives worldwide each year, and it saves millions more from suffering illness and lifelong disability (WHO estimate, 2009).

Before the introduction of routine childhood vaccination, infectious diseases were the leading cause of child's death globally. Even today these diseases cause suffering and death . Measles, Haemophilus influenza type $b$ (Hib), pertussis and neonatal tetanus being the prominent killers among vaccine-preventable diseases .

\section{Materials And Methods}

The research approach used in this study was evaluator approach. The research design used in this study was descriptive research design. 


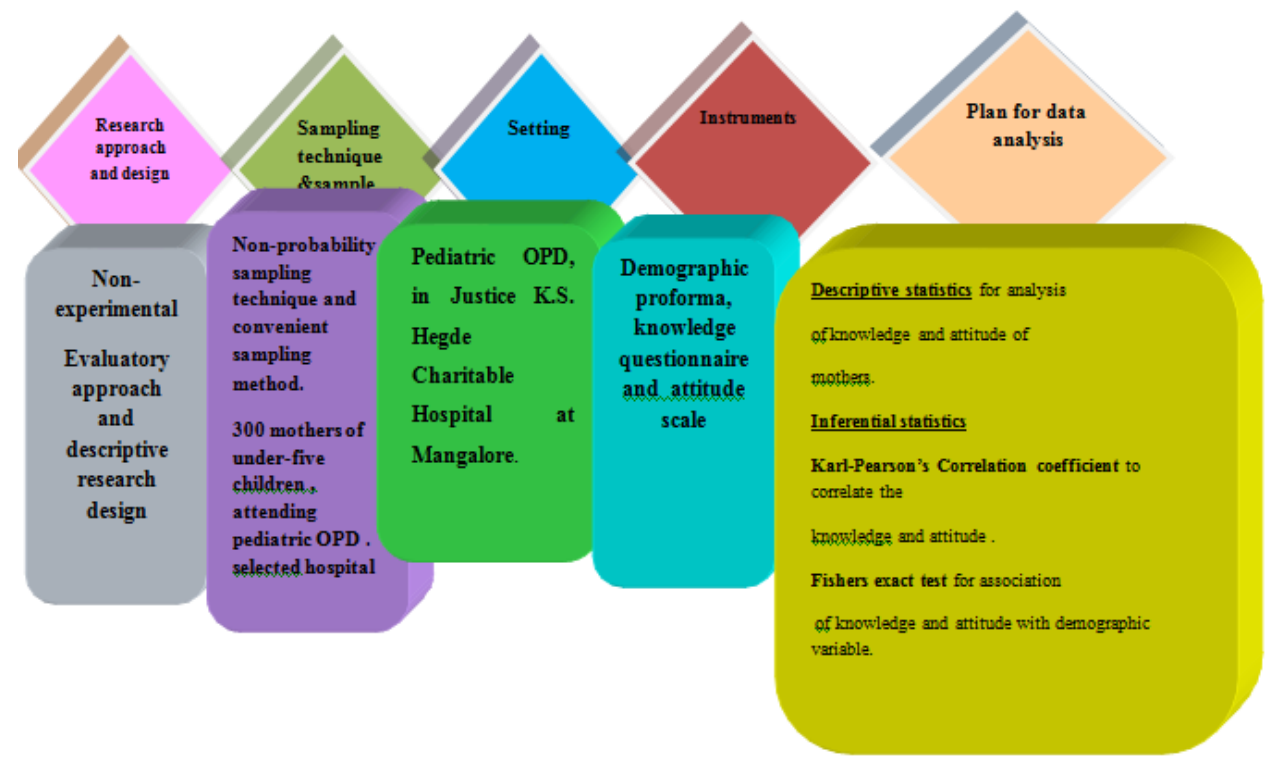

Fig:1-Schematic representation of the research design

\section{Variables}

In this study knowledge and attitude of mothers regarding vaccines are the dependent variable. This study does not have an independent variable. In this study extraneous variable were mother's age, number of underfive children, type of family, religion, area of residence, income of the family, educational status and occupation of the parents..

\section{Results}

The results of the study were organized under the following sections.

Section 1: Description of sample characteristics

Seciton 2: Assessment of knowledge regarding vaccines

Section 3: Assessment of attitude regarding vaccines

Section 4: Correlate the knowledge and attitude regarding vaccines among mothers of underfive children Section 5: Association between the knowledge regarding vaccines among mothers of underfive children with selected demographic variables

Section 6: Association between the attitude regarding vaccines among mothers of underfive children selected demographic variables

\section{Section 1: Description Of Mothers According To The Demographic Characteristics.}

Table 1: Distribution of samples according to demographic characteristics

\begin{tabular}{|c|c|c|}
\hline SAMPLE CHARACTERISTICS & FREQUENCY & $\begin{array}{c}\text { PERCENTAGE } \\
(\%)\end{array}$ \\
\hline \multicolumn{3}{|l|}{ Age in years } \\
\hline $16-20$ & 5 & 1.7 \\
\hline $21-25$ & 107 & 35.7 \\
\hline $26-30$ & 151 & 50.3 \\
\hline $31-35$ & 29 & 9.7 \\
\hline $36-40$ & 8 & 2.7 \\
\hline \multicolumn{3}{|l|}{ Religion } \\
\hline Hindu & 54 & 18 \\
\hline Muslim & 162 & 54 \\
\hline Christian & 84 & 28 \\
\hline Others & 0 & 0 \\
\hline \multicolumn{3}{|l|}{ Monthly family income (in Rs.) } \\
\hline Equal to or more than 30,375 & 0 & 0 \\
\hline $15,188-30,374$ & 0 & 0 \\
\hline $11,362-15,187$ & 23 & 7.7 \\
\hline $7,594-11,361$ & 41 & 13.7 \\
\hline $4,556-7,593$ & 158 & 52.7 \\
\hline $1,521-4,555$ & 78 & 26 \\
\hline Equal to or less than $1,520 \mathrm{Rs}$ & 0 & 0 \\
\hline
\end{tabular}




\begin{tabular}{|l|c|c|}
\hline Type of the family & 217 & 72.3 \\
\hline Nuclear family & 83 & 27.7 \\
\hline Joint family & 0 & 0 \\
\hline Extended family & \multicolumn{2}{|l|}{} \\
\hline Occupation & 148 & 49.3 \\
\hline Home maker & 8 & 2.7 \\
\hline Daily wages & 78 & 26 \\
\hline Private employee & 65 & 21.7 \\
\hline Self employed & 0 & 0 \\
\hline Government & & 74.3 \\
\hline Residential area & 223 & 25.7 \\
\hline Urban & 77 & \\
\hline Rural &
\end{tabular}

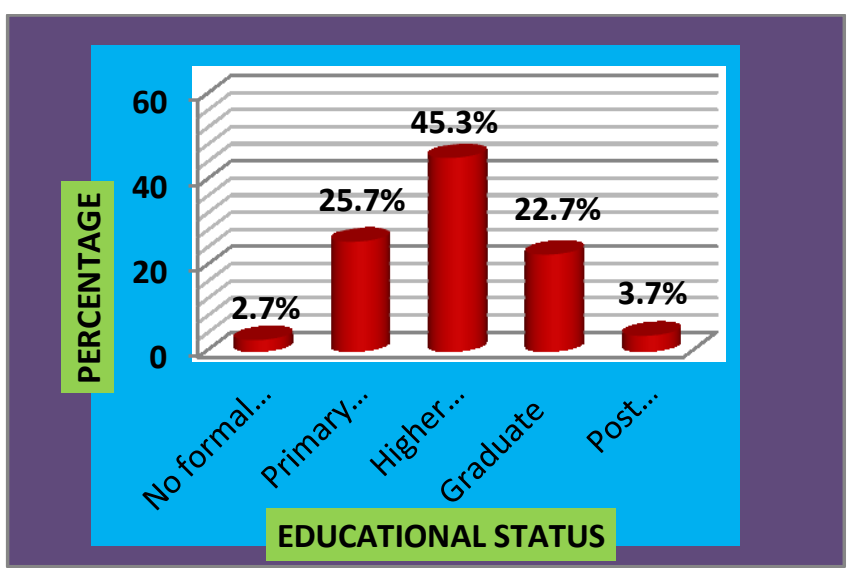

Fig-2:Cylindrical bar diagram showing distribution of samples based on educational status

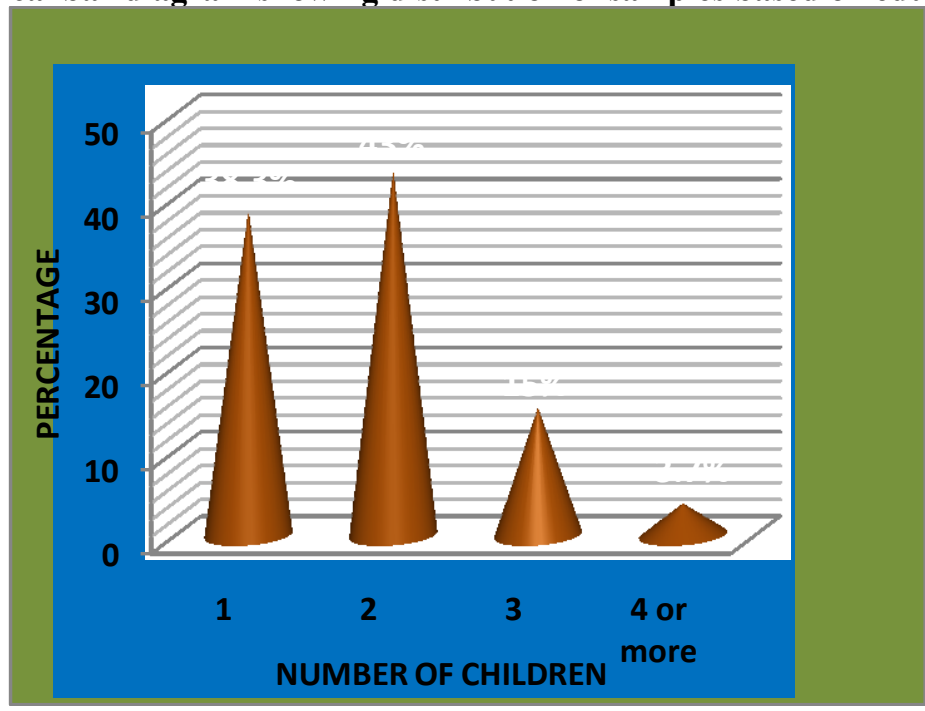

Fig-3: Cone diagram showing distribution of samples based on number of children

Section 2: Assessment Of Knowledge Regarding Vaccines Among Mothers Of Underfive Children

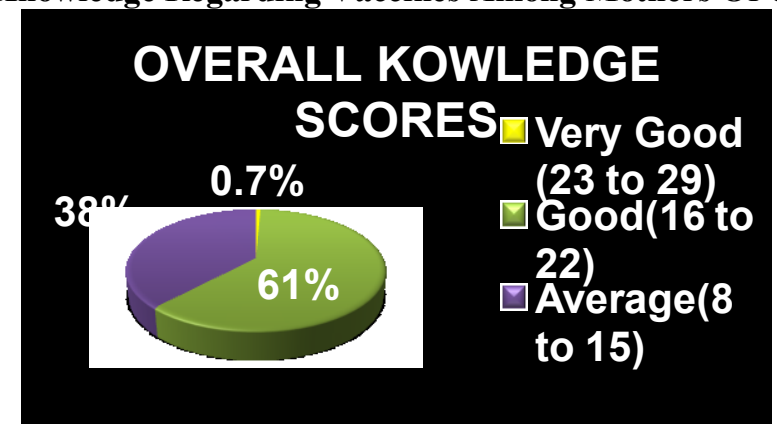

Fig-4: Pie diagram showing distribution of samples according to the overall knowledge scores. 
Table -2 Assessment of knowledge about vaccines - Area Wise

\begin{tabular}{|c|c|c|}
\hline & & $\mathbf{n}=\mathbf{3 0 0}$ \\
\hline AREA & Frequency & Percentage(\%) \\
\hline Knowledge about concept of vaccines & 300 & 100 \\
\hline Vaccines are responsible to protect the immune system. & & \\
\hline Vaccines are recommended for members of $<5$ years. & 226 & 75.33 \\
\hline c) Get the missed shot at your next visit, if you miss one or more of your child's shots. & & \\
\hline d) If child has a severe allergic reaction after a previous dose of the vaccine, child be opted out of a & 253 & 84.33 \\
\hline vaccination programme. & & \\
\hline e) Combination vaccines are mainly used to increase the potency of vaccine. & 248 & 82.66 \\
\hline If child is HIV infected, live vaccines are contraindicated. & & \\
\hline Delayed growth and development is NOT a significant factor related to vaccination. & 206 & 68.66 \\
\hline & 202 & 67.33 \\
\hline & 87 & 29 \\
\hline Knowledge about BCG & 289 & 96.33 \\
\hline a) Vaccine which prevents Tuberculosis is BCG & & \\
\hline b) Vaccines which can be given at birth are BCG, OPV & 300 & 100 \\
\hline BCG vaccine forms nodule at the site of injection. & & \\
\hline d) After BCG vaccination the papule occurs within or after 3-4 weeks & 291 & 97 \\
\hline & 279 & 93 \\
\hline Knowledge about OPV & 275 & 91.66 \\
\hline $\begin{array}{l}\text { Pulse polio programme, is an extra dose of oral polio vaccine which is given in the following months- } \\
\text { January and February }\end{array}$ & 204 & 68 \\
\hline According to the immunization schedule , 5 year old child will get a minimum 7 doses of OPV & & \\
\hline Zero dose of Polio vaccine is given at birth. & 261 & 87 \\
\hline $\begin{array}{l}\text { Knowledge about Hepatitis B } \\
\text { Hepatitis B can be prevented by a vaccine. }\end{array}$ & 266 & 88.66 \\
\hline $\begin{array}{l}\text { Babies of mothers who have positive HBsAg should be advised to be given HB immunoglobulin and HB } \\
\text { vaccine within } 24 \text { hours of birth }\end{array}$ & 44 & 14.66 \\
\hline For a neonate with birth weight less than $2000 \mathrm{gms}$, Hepatitis B Vaccine is given at, 30 days after birth & 16 & 5.3 \\
\hline & 254 & 84.66 \\
\hline $\begin{array}{l}\text { Knowledge about DPT } \\
\text { The vaccine which prevents whooping cough is DPT. }\end{array}$ & 259 & 86.33 \\
\hline Minimal interval between 2 doses of OPV and DPT should be 4 weeks & 45 & 15 \\
\hline $\begin{array}{l}\text { DT vaccine can be given in } 2 \text { doses with a } 6 \text { week interval if the child has not been given the DPT vaccine } \\
\text { until } 5 \text { years, }\end{array}$ & 26 & 8.66 \\
\hline $\begin{array}{l}\text { Knowledge about measles } \\
\text { Measles vaccine is given at the age of } 9 \text { months }\end{array}$ & 280 & 93.33 \\
\hline The combination vaccine MMR represents/stands for Measles, Mumps, Rubella & 24 & 8 \\
\hline MMR is given at the age of $15-18$ months & 267 & 89 \\
\hline $\begin{array}{l}\text { Knowledge about Varicella vaccine } \\
\text { Chicken pox can be prevented by the Varicella vaccine }\end{array}$ & 11 & 3.66 \\
\hline $\begin{array}{l}\text { Knowledge about typhoid vaccine } \\
\text { Revaccination of typhoid vaccine should be done at } 3-4 \text { years }\end{array}$ & 1 & 0.33 \\
\hline $\begin{array}{l}\text { 9. Knowledge about Hib vaccine } \\
\text { a) } 4-5 \text { doses of Hib vaccine is required for children. }\end{array}$ & 0 & 0 \\
\hline b) Brain fever and pneumonia can be prevented by, Hib vaccine & 5 & 1.66 \\
\hline $\begin{array}{l}\text { Knowledge about Rotavirus vaccine } \\
\text { Rotavirus vaccine is available to prevent diarrhea }\end{array}$ & 0 & 0 \\
\hline
\end{tabular}

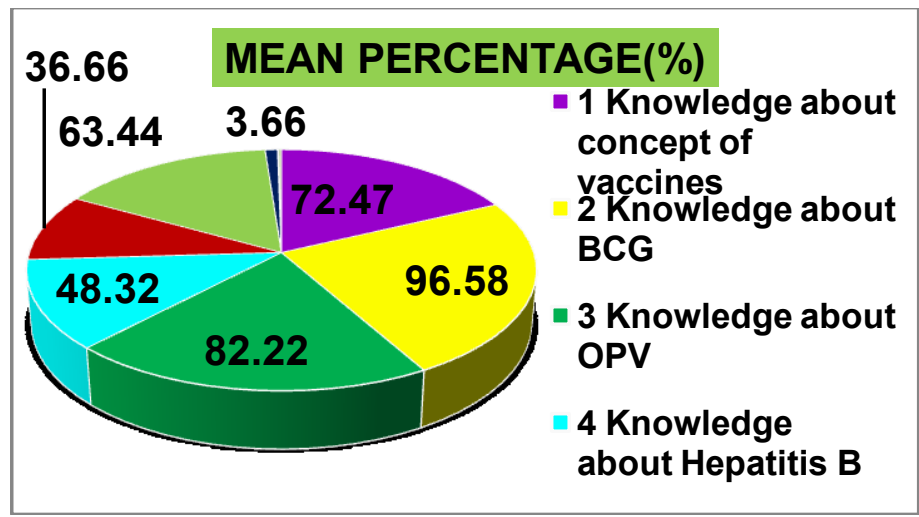

Fig-5: Pie diagram showing mean percentage distribution of mothers knowledge about vaccines- Area wise. 
A Study on Knowledge and Attitude Regarding Vaccines among Mothers of Under Five ....

Section-3: Assessment Of Attitude Regarding Vaccines Among Mothers Of Underfive Children

Table-3 Distribution of samples according to overall attitude scores.

\begin{tabular}{|l|c|c|}
\hline Category & Frequency & Percentage(\%) \\
\hline Very good $(80$ to 95$)$ & 62 & 20.7 \\
\hline Good $(60$ to 80$)$ & 206 & 68.7 \\
\hline Average(40 to 60$)$ & 31 & 10.3 \\
\hline Poor $(20$ to 40$)$ & 0 & 0 \\
\hline
\end{tabular}

$\mathbf{n}=\mathbf{3 0 0}$

Section 4: Correlate The Knowledge And Attitude Regarding Vaccines Among Mothers Of Under-Five Children

Table-4: orrelation between the knowledge and attitude regarding vaccines among mothers of underfive children.

\begin{tabular}{|c|l|c|c|c|}
\hline VARIABLE & MEAN & S.D. & $\begin{array}{c}\text { KARL-PEARSON } \\
\text { CORRELATION } \\
\text { COEFFICIENT } \\
(\mathbf{r})\end{array}$ & p-VALUE \\
\hline Knowledge & 16.2367 & 3.05260 & $\mathbf{0 . 5 8 9}$ & 0.001 \\
Attitude & 71.53 & 8.31140 & & $\begin{array}{c}\mathrm{p}<0.01 \\
\mathrm{~S}\end{array}$ \\
\hline
\end{tabular}

$\mathbf{n}=\mathbf{3 0 0}$

Section 5: Association between the knowledge regarding vaccines among mothers of underfive children with selected demographic variables

Table-5 : Association between knowledge regarding vaccines among mothers of under-five children with selected demographic variables:

\begin{tabular}{|c|c|c|c|c|c|}
\hline \multirow[t]{2}{*}{ Variables } & \multicolumn{4}{|c|}{ Knowledge rating } & \multirow[t]{2}{*}{ LOS } \\
\hline & $\begin{array}{l}\text { Poor } \\
(0-7)\end{array}$ & $\begin{array}{c}\text { Average } \\
(8-15)\end{array}$ & $\begin{array}{c}\text { Good } \\
(16-22)\end{array}$ & $\begin{array}{l}\text { Very good } \\
(23-29)\end{array}$ & \\
\hline $\begin{array}{l}\text { Age } \\
15-20 \\
20-25 \\
25-30 \\
30-35 \\
35-40\end{array}$ & $\begin{array}{l}0 \\
0 \\
0 \\
0 \\
0\end{array}$ & $\begin{array}{c}4 \\
68 \\
41 \\
1 \\
0 \\
\end{array}$ & $\begin{array}{c}1 \\
39 \\
109 \\
28 \\
7 \\
\end{array}$ & $\begin{array}{l}0 \\
0 \\
1 \\
0 \\
1\end{array}$ & $\begin{array}{l}0.001 \\
\mathrm{P}<0.05 \\
\mathrm{~S}\end{array}$ \\
\hline $\begin{array}{l}\text { 2.Educational status } \\
\text { No formal education } \\
\text { Primary school } \\
\text { Higher primary and high school } \\
\text { Graduate } \\
\text { Post graduate }\end{array}$ & $\begin{array}{l}0 \\
0 \\
0 \\
0 \\
0\end{array}$ & $\begin{array}{c}4 \\
43 \\
57 \\
8 \\
2\end{array}$ & $\begin{array}{c}3 \\
33 \\
79 \\
60 \\
9 \\
\end{array}$ & $\begin{array}{l}1 \\
1 \\
0 \\
0 \\
0\end{array}$ & $\begin{array}{l}0.001 \\
\mathrm{P}<0.05 \\
\mathrm{~S}\end{array}$ \\
\hline $\begin{array}{l}\text { 3.Religion } \\
\text { Hindu } \\
\text { Muslim } \\
\text { Christian } \\
\text { others } \\
\end{array}$ & $\begin{array}{l}0 \\
0 \\
0 \\
0\end{array}$ & $\begin{array}{c}21 \\
72 \\
21 \\
0 \\
\end{array}$ & $\begin{array}{c}33 \\
89 \\
62 \\
0 \\
\end{array}$ & $\begin{array}{l}0 \\
1 \\
1 \\
0\end{array}$ & $\begin{array}{l}0.021 \\
\mathrm{P}<0.05 \\
\mathrm{~S}\end{array}$ \\
\hline $\begin{array}{l}\text { 4. Monthly family income (in Rs.) } \\
\text { Equal to or more than } 30,375 \\
15,188-30,374 \\
11,362-15,187 \\
7,594-11,361 \\
4,556-7,593 \\
1,521-4,555 \\
\text { Equal to or less than } 1,520\end{array}$ & $\begin{array}{l}0 \\
0 \\
0 \\
0 \\
0 \\
0\end{array}$ & $\begin{array}{c}0 \\
\\
0 \\
7 \\
6 \\
64 \\
37 \\
0\end{array}$ & $\begin{array}{c}0 \\
\\
0 \\
16 \\
35 \\
93 \\
40 \\
0\end{array}$ & $\begin{array}{l}0 \\
0 \\
0 \\
0 \\
1 \\
1 \\
0\end{array}$ & $\begin{array}{c}0.005 \\
\mathrm{P}<0.05 \\
\mathrm{~S}\end{array}$ \\
\hline $\begin{array}{l}\text { 5. Type of family } \\
\text { Nuclear } \\
\text { Joint } \\
\text { extended }\end{array}$ & $\begin{array}{l}0 \\
0 \\
0\end{array}$ & $\begin{array}{c}77 \\
37 \\
0 \\
\end{array}$ & $\begin{array}{c}138 \\
46 \\
0 \\
\end{array}$ & $\begin{array}{l}2 \\
0 \\
0\end{array}$ & $\begin{array}{c}0.265 \\
\mathrm{p}>0.05 \\
\mathrm{NS}\end{array}$ \\
\hline $\begin{array}{l}\text { 6. Occupation } \\
\text { Home maker } \\
\text { Daily wages } \\
\text { Private employee } \\
\text { Self-employed } \\
\text { government } \\
\end{array}$ & $\begin{array}{l}0 \\
0 \\
0 \\
0 \\
0\end{array}$ & $\begin{array}{c}71 \\
5 \\
11 \\
26 \\
0\end{array}$ & $\begin{array}{c}75 \\
3 \\
67 \\
39 \\
0\end{array}$ & $\begin{array}{l}2 \\
0 \\
0 \\
0 \\
0\end{array}$ & $\begin{array}{c}0.001 \\
\mathrm{P}<0.05 \\
\mathrm{~S}\end{array}$ \\
\hline $\begin{array}{c}\text { 7. Number of children } \\
1\end{array}$ & 0 & 87 & 28 & 0 & 0.001 \\
\hline
\end{tabular}

$\mathbf{n}=\mathbf{3 0 0}$ 


\begin{tabular}{|c|c|c|c|c|c|}
\hline $\begin{array}{c}2 \\
3 \\
4 \text { or more } \\
\end{array}$ & $\begin{array}{l}0 \\
0 \\
0\end{array}$ & $\begin{array}{c}24 \\
1 \\
2\end{array}$ & $\begin{array}{c}105 \\
42 \\
9\end{array}$ & $\begin{array}{l}0 \\
2 \\
0\end{array}$ & $\begin{array}{l}\mathrm{P}<0.05 \\
\mathrm{~S}\end{array}$ \\
\hline $\begin{array}{l}\text { 8.Residential area } \\
\text { Urban } \\
\text { Rural }\end{array}$ & $\begin{array}{l}0 \\
0\end{array}$ & $\begin{array}{l}81 \\
33\end{array}$ & $\begin{array}{c}141 \\
43\end{array}$ & $\begin{array}{l}1 \\
1\end{array}$ & $\begin{array}{l}0.290 \\
\mathrm{P}>0.05 \\
\text { NS }\end{array}$ \\
\hline
\end{tabular}

Section 6: Association between the attitude regarding vaccines among mothers of underfive children with selected demographic variables.

Table:6: Association between attitude regarding vaccines among mothers of underfive children with selected demographic variables:

\begin{tabular}{|c|c|c|c|c|c|}
\hline \multirow[t]{2}{*}{ Variables } & \multicolumn{4}{|c|}{ attitude rating } & \multirow[t]{2}{*}{ LOS } \\
\hline & $\begin{array}{c}\text { Poor } \\
(20-40)\end{array}$ & $\begin{array}{c}\text { Average } \\
(40-60)\end{array}$ & $\begin{array}{c}\text { Good } \\
(60-80)\end{array}$ & $\begin{array}{c}\text { Very good } \\
(80-95)\end{array}$ & \\
\hline $\begin{array}{l}\text { 1.Age in years } \\
15-20 \\
20-25 \\
25-30 \\
30-35 \\
35-40\end{array}$ & $\begin{array}{l}0 \\
0 \\
0 \\
0 \\
0\end{array}$ & $\begin{array}{c}1 \\
21 \\
9 \\
0 \\
0\end{array}$ & $\begin{array}{c}4 \\
72 \\
110 \\
16 \\
4\end{array}$ & $\begin{array}{c}0 \\
13 \\
32 \\
13 \\
4\end{array}$ & $\begin{array}{l}0.001 \\
\mathrm{P}<0.05 \\
\mathrm{~S}\end{array}$ \\
\hline $\begin{array}{l}\text { 2.Educational status } \\
\text { No formal education } \\
\text { Primary school } \\
\text { Higher primary and high school } \\
\text { Graduate } \\
\text { Post graduate }\end{array}$ & $\begin{array}{l}0 \\
0 \\
0 \\
0 \\
0\end{array}$ & $\begin{array}{c}0 \\
19 \\
11 \\
1 \\
0\end{array}$ & $\begin{array}{c}7 \\
44 \\
105 \\
42 \\
8\end{array}$ & $\begin{array}{c}1 \\
13 \\
20 \\
25 \\
3\end{array}$ & $\begin{array}{l}0.001 \\
\mathrm{P}<0.05 \\
\quad \mathrm{~S}\end{array}$ \\
\hline $\begin{array}{l}\text { 3.Religion } \\
\text { Hindu } \\
\text { Muslim } \\
\text { Christian } \\
\text { others }\end{array}$ & $\begin{array}{l}0 \\
0 \\
0 \\
0\end{array}$ & $\begin{array}{c}2 \\
26 \\
3 \\
0\end{array}$ & $\begin{array}{c}46 \\
99 \\
61 \\
0\end{array}$ & $\begin{array}{c}6 \\
36 \\
20 \\
0\end{array}$ & $\begin{array}{c}0.002 \\
\mathrm{P}<0.05 \\
\mathrm{~S}\end{array}$ \\
\hline $\begin{array}{l}\text { 4.Monthly family income (in Rs } \\
\text { Equal to or more than } 30,375 \\
15,188-30,374 \\
11,362-15,187 \\
7,594-11,361 \\
4,556-7,593 \\
1,521-4,555 \\
\text { Equal to or less than } 1,520\end{array}$ & $\begin{array}{l}0 \\
0 \\
0 \\
0 \\
0 \\
0 \\
0\end{array}$ & $\begin{array}{c}0 \\
0 \\
1 \\
0 \\
23 \\
7 \\
0\end{array}$ & $\begin{array}{c}0 \\
0 \\
17 \\
30 \\
111 \\
48 \\
0\end{array}$ & $\begin{array}{c}0 \\
0 \\
5 \\
11 \\
24 \\
22 \\
0\end{array}$ & $\begin{array}{l}0.018 \\
\mathrm{P}<0.05 \\
\quad \mathrm{~S}\end{array}$ \\
\hline $\begin{array}{l}\text { 5. Type of family } \\
\text { Nuclear } \\
\text { Joint } \\
\text { extended }\end{array}$ & $\begin{array}{l}0 \\
0 \\
0\end{array}$ & $\begin{array}{c}18 \\
13 \\
0\end{array}$ & $\begin{array}{c}150 \\
56 \\
0\end{array}$ & $\begin{array}{c}48 \\
14 \\
0\end{array}$ & $\begin{array}{l}0.215 \\
\mathrm{p}>0.05 \\
\quad \mathrm{NS}\end{array}$ \\
\hline $\begin{array}{l}\text { 6. Occupation } \\
\text { Home maker } \\
\text { Daily wages } \\
\text { Private employee } \\
\text { Self-employed } \\
\text { government }\end{array}$ & $\begin{array}{l}0 \\
0 \\
0 \\
0 \\
0\end{array}$ & $\begin{array}{c}24 \\
1 \\
2 \\
4 \\
0\end{array}$ & $\begin{array}{c}100 \\
6 \\
54 \\
45 \\
0\end{array}$ & $\begin{array}{c}23 \\
1 \\
22 \\
16 \\
0\end{array}$ & $\begin{array}{c}0.028 \\
\mathrm{P}<0.05 \\
\mathrm{~S}\end{array}$ \\
\hline $\begin{array}{c}\text { 7.Number of children } \\
1 \\
2 \\
3 \\
4 \text { or more }\end{array}$ & $\begin{array}{l}0 \\
0 \\
0 \\
0\end{array}$ & $\begin{array}{c}24 \\
6 \\
0 \\
1\end{array}$ & $\begin{array}{c}78 \\
94 \\
26 \\
8\end{array}$ & $\begin{array}{c}12 \\
29 \\
19 \\
3\end{array}$ & $\begin{array}{l}0.001 \\
\mathrm{P}<0.05 \\
\quad \mathrm{~S}\end{array}$ \\
\hline $\begin{array}{cc}\text { 8.Residential } & \text { area } \\
\bullet & \text { Urban } \\
\bullet & \text { Rural }\end{array}$ & $\begin{array}{l}0 \\
0\end{array}$ & $\begin{array}{l}20 \\
11\end{array}$ & $\begin{array}{l}161 \\
45\end{array}$ & $\begin{array}{l}41 \\
21\end{array}$ & $\begin{array}{l}0.097 \\
\mathrm{P}>0.05 \\
\mathrm{NS}\end{array}$ \\
\hline
\end{tabular}

\section{Discussion}

Section 1: Description of samples according to the demographic characteristics

The findings revealed that majority, 151 (50.3\%) mothers belongs to the age group between 26-30 years and majority,136 (45.3\%) mothers have completed higher primary and high school education. The findings were contradictory ,in a similar study done by Rachna Kapoor in Ahmedabad about the awareness and knowledge of mothers of under five children regarding immunization. The study revealed that $73 \%$ of the mothers belonged to the age group of 21-30 years. A similar study done by Rachna Kapoor in Ahmedabad about the awareness and knowledge of mothers of under five children regarding immunization, revealed that $29 \%$ of the mothers had secondary education. Majority of the mothers $162(54 \%)$ were muslims and $158(52.7 \%)$ had 
income between Rs.4,556- Rs.7,593. Results were contradictory in a study done by Rachna Kapoor in Ahmedabad about the awareness and knowledge of mothers of under five children regarding immunization , revealed that most of the subjects $65 \%$ belongs to Hindu religion. Most ,217 (72.3\%) mothers belongs to nuclear family. Majority, 148 (49.3\%) mothers were home makers. In a similar study done by Rachna Kapoor in Ahmedabad about the awareness and knowledge of mothers of under five children regarding immunization ,the results shows that $72 \%$ of the mothers were housewives. Nearly half, 129 (49\%) mothers had 2 children. Majority, $223(74.3 \%)$ mothers belongs to urban area. In a similar study conducted in New Zealand on mothers knowledge and attitude towards immunization revealed that, majority (500) of the mothers belongs to urban area.

\section{Section 2: Assessment Of Knowledge Regarding Vaccines Among Mothers Of Under-Five Children .}

More than half of the of the mothers $184(61.3 \%)$ had 'good' knowledge regarding vaccines. In a similar study KAP study done by Shamila Hamid in North Kashmir (2011), about "Immunization of children in a Rural Area of North Kashmir, India: A KAP study" revealed that $39 \%$ of the mothers knew about OPV and only $1 \%$ were aware of protective role of BCG. In this study $99 \%$ of the mothers were ignorant about the disease for which BCG is used. $259(86.33 \%)$ mothers knew that vaccine which prevents whooping cough is DPT. Only $26(8.66 \%)$ mothers were knowledgeable about the measures that can be done if the child has not been given DPT. Results were contradictory in a similar KAP study done by Shamila Hamid in North Kashmir (2011), about "Immunization of children ", revealed that only $20 \%$ of the mothers were knowing the disease prevented by DPT vaccination. None of the mothers were aware about the doses of Hib vaccine . Only 5 $(1.66 \%)$ mothers knew that brain fever and pneumonia can be prevented by Hib vaccine. An internet based survey on parental attitudes towards immunization was performed by the use of a German internet vaccine forum for lay persons. This study revealed that parents considered Hib vaccine as least important for their children.

\section{Section-3: Assessment Of Attitude Regarding Vaccines Among Mothers Of Under-Five Children Attending Pediatric Opd In A Selected Hospital At Mangalore}

In the present study the majority $206(68.7 \%)$ mothers has good attitude. The highest score was 88 and the lowest was 52 .

In a similar study done by Shamila Hamid in North Kashmir (2011), about " Immunization of children in a Rural Area of North Kashmir, India: A KAP study" revealed that all the mothers(100\%) had good attitude towards immunization.

\section{Section 6: Association Between The Attitude Regarding Vaccines Among Mothers Of Under-Five Children With Selected Demographic Variables.}

The study findings shows that there was a significant association of attitude with age, educational status, religion, monthly family income, occupation, and the number of children. The $\mathrm{p}<0.05$, the research hypothesis H3 was accepted, that is, there will be a significant association between attitude of mothers with selected demographic variables.

In a similar study conducted on status of mother's KAP on child immunization in minority areas in Guizhou Province shown that mothers' knowledge, attitudes and practices on childhood immunization were at a low level and influenced by educational background, country's economic level, mother's age, household size and ethnic group.

\section{Conclusion}

Therefore, the findings of the study shows that the public health nurse have a vital role in creating health consciousness among the people and also to identify children who are at risk by periodic assessment of children. Mothers need education on importance of National Immunization Schedule and adherence to the timings in the given immunization card. Educational campaigns will help to reduce the incidence of VaccinePreventable Diseases. Nursing practice optimally enables mothers to examine what is known and make choice that best fit for their children.

\section{Acknowledgements}

The success of this study would not have been possible without the help, guidance and contribution of the teachers, family, well- wishers and all dear ones. I would like to express my gratitude to all those who gave me their blessings and support to complete this thesis.

At the outset I am deeply indebted to God almighty for his blessings throughout the study. With this, my heart overflows with gratitude to Lord Almighty for bestowing his grace and blessings up on me day after day especially throughout this study 
My heartfelt thanks with sincere gratitude and respect to my guide

Prof. (Mrs) Sujatha.R, Dept of Child Health Nursing for her inspiring guidance, valuable suggestions, timely advice, constant encouragement and support for the completion of this study. Words are not sufficient to acknowledge her guidance without which it would not have been possible to complete this work.

I am deeply indebted to my beloved parents. I owe my success to them who made this task possible through their constant prayers, unconditional support and encouragement.

Any work which will bring about with success only when he or she is being supported by others. With a great sense of gratitude I, the investigator, owe deep heartfelt thankfulness to all those who have paid the coin of support and guidance to the successful completion of this study.

\section{References}

[1]. United Nations Foundation. "All About Vaccines". Available at http://www.shot-life-allaboutvaccinesapril2012.pdf

[2]. "How vaccines prevent disease". Available at: www.valueoptions.com/solutions/2011/08-August/story1.htm

[3]. Borras E. "Parental knowledge of paediatric vaccination". 2009, May27. Available at www.biomedcentral.com/1471-2458/9/154.

[4]. Available at www.unicef.org/infobycountry/india-background.html

[5]. European Immunization Week. "Seven Key Reasons"- World Health Organization Regional Office. Available at www.euro.who.int/-data/assets/pdf-file/.....seven-key-reasons.pdf

[6]. Sharma Suresh. "Immunization coverage in India", Institute of Economic Growth. University Enclave, Delhi, India. Available from URL: http://www.iegindia.org/workpap/wp283.pdf

[7]. Centers for Disease Control and Prevention (CDC). "Progress towards introduction of Hib vaccine in low income countries worldwide”. MMWR Morb Mortal Wkly Re. Feb.57(6);2008,Pp:148151. Available at www.cdc.gov/mmwr/preview/mmwrhtml/mm570693.htm

[8]. Chadha M S,Lole K S, Bora M H, et.al. "Transactions of the Royal Society of Tropical Medicine and Hygiene. ISSN 0035-9203. Available from URL:http://cat.instr.fr/?Modele=afficheN\&EPSIDT=21980430

[9]. UNICEF. "The State of World's Children Report”. July 2008. Available at www.unicef.org/sowc08/docs/sowc08.pdf

[10]. UNICEF. "The State of World's Children Report". 2012. Available at www.unicef.org/...sowc2012-main-report-EN21Dec2011.pdf

[11]. Patel MM, Parashar UD. "Assessing the effectiveness and public health impact of rotavirus vaccines after introduction in immunization programs".

[12]. JinfectDis.2009 Nov1; $200 \quad$ Suppl1: S291. Available http://www.ncbi.nlm.nih.gov/pubmed/19817612?itool=EntrezSystem2.PEntrez.Pubmed.Pubmed ResultsPanel

[13]. Rachna Kapoor, Vyas Sheetal. "Awareness and knowledge of mothers of under-five children regarding immunization in Ahmedabad”. Volume I.Issue 1. JulyDecember2010,Pp:1215.AvailablefromURL:http;//www.iapsmgc.org/oa2

[14]. .pdf National Family Health Survey(NFHS-3). 2006.Available at www.rchiips.org/NFHS/nfhs3.shtml 